\title{
Parents' Motivation in Choosing Bilingual School for Early Childhood
}

\author{
Winarti Agustina \\ Institut Agama Kristen Negeri Tarutung \\ winarti1708@gmail.com
}

\begin{abstract}
This study aims to describe the aspects that cause parents to get motivated in choosing bilingual kindergarten for their children in Bekasi and to find out which aspects are dominant. This descriptive research used a quantitative research method. The research method used in this study is conducted through a survey. 205 parents with children up to six years old (early childhood) in Bekasi are the subjects of this study. Data collection techniques are implemented using multilevel scale questionnaire. The results appeared that what makes parents get motivated in choosing bilingual school for their children are derived from internal and external motivation. Internal motivation consists of (1) aspects of needs and (2) aspects of hope, while external motivation includes (3) aspects of child's talents and interests, (4) aspects of psychology, (5) aspects of friends, (6) aspects of facilities and infrastructure, and (7) aspects of teacher. The results are based on average differences in the questionnaire from seven aspects with the breakdown: aspects of needs for 3.40, aspects of hope for 3.39, aspects of child's talents and interests for 3.22, aspects of psychology for 3.20, aspects of friends for 3.42, aspects of facilities and infrastructure for 3.22, and aspects of teacher for 3.24. Descriptively, the aspects that influence parents in choosing bilingual school are aspects of friends. The seven aspects were tested by Tukey's HSD to analyze the variety by comparing these seven aspects and seeing the average similarity. Thus, motivation variable significantly influences the differences in the aspects of psychology, children's talents and interests, facilities and infrastructure, and teachers with the aspects of hopes, needs, and friends.
\end{abstract}

Keywords: motivation, bilingual, early childhood

\begin{abstract}
Abstrak: Tujuan penelitian ini untuk mendeskripsikan aspek-aspek yang menyebabkan orangtua termotivasi memilih sekolah bilingual untuk anaknya di Kota Bekasi. Selain itu, untuk mengetahui aspek dominan motivasi orangtua memilih sekolah bilingual untuk anaknya. Pendekatan penelitian yang digunakan adalah kuantitatif dengan jenis penelitian deskriptif. Metode yang digunakan yaitu survey. Subjek penelitian ini berjumlah 205 orangtua yang memiliki anak usia dini di Kota Bekasi. Teknik pengumpulan data menggunakan kuesioner skala bertingkat. Penelitian ini menjelaskan bahwa aspek-aspek yang menyebabkan orangtua termotivasi memilih sekolah bilingual untuk anaknya adalah adanya motivasi internal dan eksternal. Motivasi intrinsik terdiri dari (1) kebutuhan dan (2) harapan. Sedangkan motivasi ekstrinsik terdiri dari (3) bakat dan minat anak, (4) psikologi, (5) teman, (6) sarana dan prasarana, serta (7) guru. Hasil penelitian ini yaitu berdasarkan perbedaan rata-rata kuesioner dari ketujuh aspek dengan rincian rata-rata aspek kebutuhan sebesar 3.40, aspek harapan sebesar 3.39, aspek bakat dan minat anak sebesar 3.22, aspek psikologi sebesar 3.20, aspek teman sebesar 3.42, aspek sarana dan prasarana sebesar 3.22, serta aspek guru sebesar 3.24. Secara deskriptif rata-rata aspek yang paling mempengaruhi motivasi orangtua memilih sekolah bilingual untuk anaknya adalah aspek teman. Ketujuh aspek tersebut dilakukan pengujian Tukey's HSD untuk analisis varian dengan membandingkan ketujuh aspek tersebut dan melihat kesamaan rata-rata. Dengan demikian, variabel motivasi berpengaruh secara signifikan terhadap perbedaan psikologi, bakat dan minat anak, sarana dan prasarana, serta guru dengan harapan, kebutuhan, dan teman.
\end{abstract}

Kata Kunci: motivasi, bilingual, anak usia dini

\section{INTRODUCTION}

Early childhood at the age of 0-6 years is often referred to as golden age. Children at this age really need more attention since they still need help from adults to fulfill their physical and spiritual needs. Help from parents for their children is intended to maximize 
children's development and growth. One of the attempts parents can do to maximize children's development and growth is through paying attention to the principles of PAUD since all efforts made by parents must focus on the stages of child development.

According to the Law of the Republic of Indonesia Number 20 of 2003 regarding National Education system in article 1 paragraph 14 (Kementerian Pendidikan dan Kebudayaan RI (2003), early childhood education is aimed at children from birth until the age of six years, in which they need to be provided by educational stimuli to help fulfill their physical and spiritual growth and development. By that, children will be ready to enter higher education.

Education also needs to pay attention to each child's needs. A research conducted by Jambunathan (2005:280), found that early childhood educators need to pay attention to their teaching strategies to fulfill the needs of children and families better.

One important aspect in this globalization era is language. Some parents prepare early to make their children master more than one language with the purpose to get a better future, as it is supported by a research conducted by Prošić-Santovac \& Radović (2018: 289), "when foreign languages are taught at pre-primary level, English is a constant on the learning menu. Similarly to some other European countries, Serbia, as a country with prevalent multilingualism, shows a preference for early foreign language learning, with English being one of the most frequent choices of parents for their children". Schools that support foreign or bilingual languages are the schools most parents choose for their children.

However, the concept results in a contradiction in the society. There is an assumption that giving a second language for children will have a negative effect on children's cognitive, and some say that a second language has a positive impact on children's cognitive. According to Schinke \& Liano (1989: 227-228), the issue of bilingual cognitive effects in recent studies showed no influence on complex interactions, children's mental age, and language proficiency level.

Some reasons why parents are choosing bilingual schools are found, as in Nasser's study (2011: 315) that concluded Palestinian and Jewish parents prefer bilingual school for their children's education. Bilingual education has its function as an effective empowerment tool to balance their children's needs and desires. In this study, it would reveal the reasons on why parents prefer bilingual schools, and it is simply because of the purpose of having access to better education.

Previous research have made the researchers dig deeper into the background and issue of why parents prefer bilingual schools for their early childhood. Based on data from Dinas Pendidikan Kota Bekasi-West Java, there are 45 public schools and 1341 private schools in Bekasi. These are not small numbers and are considered enough to maximize early childhood education in Bekasi City.

\section{METHODS}

This research used a survey method. The data collected were then analyzed using a quantitative approach with descriptive statistics. Researchers searched deeper to the reasons why parents are motivated to prefer bilingual school. 205 parents with children up to six years old (early childhood) in Bekasi are the subjects of this study. Data collection techniques used in this study were questionnaires and documentation. 


\section{RESULTS}

This study was carried out in four international standard kindergartens, including Tunas Jakasampura kindergarten, Tunas Global kindergarten, Ar Rahmah kindergarten, and Ibnu Sina kindergarten. The instrument that has been compiled with a total of 48 items consists of aspects of the needs, hope, talents and interests, psychology, friends, facilities and infrastructure, and teachers. After the data were collected, the researcher organized the data into several aspects then counted the total numbers of parents who had scores of 1-4. Score 1 in each question is for parents who strongly disagree with the statements in the questionnaire. Score 2 is for parents who disagree with the statements in the questionnaire. Score 3 is for parents who agree with the statements, and score 4 is for parents who really agree with the statements in the questionnaire. Here are the average results from the seven aspects examined:

\section{Table 1. Average Difference of Compared Aspects}

\section{Descriptive}

Motivation

\begin{tabular}{|c|c|c|c|c|c|c|c|c|}
\hline & \multirow[b]{2}{*}{$\mathbf{N}$} & \multirow[b]{2}{*}{ Mean } & \multirow{2}{*}{$\begin{array}{l}\text { Std. } \\
\text { Deviatio } \\
\text { n }\end{array}$} & \multirow[b]{2}{*}{$\begin{array}{l}\text { Std. } \\
\text { Error }\end{array}$} & \multicolumn{2}{|c|}{$\begin{array}{l}95 \% \text { Confidence } \\
\text { Interval for Mean }\end{array}$} & \multirow[b]{2}{*}{ Minimum } & \multirow[b]{2}{*}{ Maximum } \\
\hline & & & & & $\begin{array}{l}\text { Lower } \\
\text { Bound }\end{array}$ & $\begin{array}{l}\text { Upper } \\
\text { Bound }\end{array}$ & & \\
\hline Needs & 3074 & 3.40 & .494 & .009 & 3.39 & 3.42 & 2 & 4 \\
\hline Hope & 2665 & 3.39 & .488 & .009 & 3.37 & 3.41 & 3 & 4 \\
\hline $\begin{array}{l}\text { Talents and } \\
\text { Interests }\end{array}$ & 1230 & 3.22 & .411 & .012 & 3.19 & 3.24 & 3 & 4 \\
\hline Psychology & 1025 & 3.20 & .404 & .013 & 3.18 & 3.23 & 3 & 4 \\
\hline Friends & 410 & 3.42 & .495 & .024 & 3.38 & 3.47 & 3 & 4 \\
\hline $\begin{array}{l}\text { Facilities and } \\
\text { Infrastructure }\end{array}$ & 820 & 3.22 & .415 & .014 & 3.19 & 3.25 & 3 & 4 \\
\hline Teacher & 615 & 3.24 & .427 & .017 & 3.21 & 3.27 & 3 & 4 \\
\hline Total & 9839 & 3.33 & .472 & .005 & 3.32 & 3.34 & 2 & 4 \\
\hline
\end{tabular}

From the result above, we can see the average difference from these seven aspects with the highest average aspect relied on the aspect of friends. Researchers also conducted similarity of variant testing, as follows:

\section{Table 2. Similarity of Variant Testing}

Test of Homogeneity of Variances

Motivation

\begin{tabular}{llll} 
Levene Statistic & df1 & df2 & Sig. \\
\hline 288.976 & 6 & 9832 & .000 \\
\hline
\end{tabular}

From the result above, Levene statistics rate obtained 288.976 with a significance/probability (sig) of 0,000 . Since the probability or significance counted $<0.05\left(0.000<0.05 ; \mathrm{H}_{0}\right.$ was rejected and $\mathrm{H}_{1}$ was accepted. In conclusion, the variant errors of these seven aspects being compared are different.

ANOVA test was also conducted to prove whether all seven aspects have different or the same average results. Following are the results of testing the hypothesis as presented in the graph: 


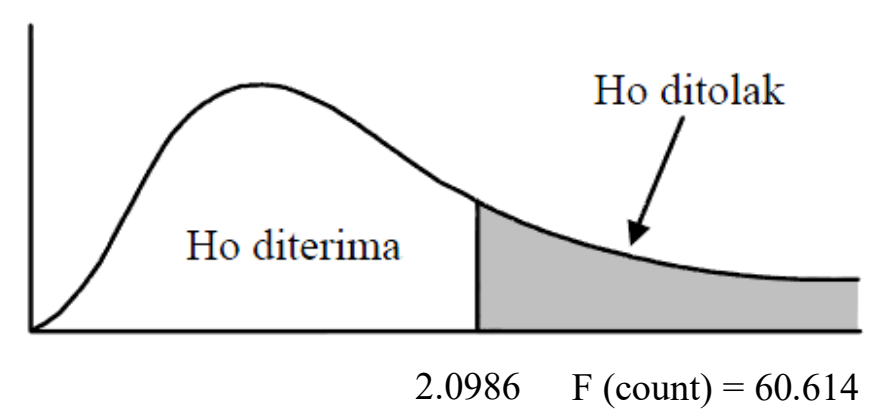

Picture 1. Hypothesis Testing Chart

$\mathrm{F}_{\text {count }}$ falls in the area of rejection, so $\mathrm{H}_{0}$ is rejected and $\mathrm{H}_{1}$ is accepted. To conclude, the average of these seven aspects is significantly different.

Post-Hoc Test is also used by researchers to find which groups are on average of the same aspects or on average of the different aspects, including:

1. Needs vs Hope

The average of needs and hope aspects is the same, and the average difference between these two aspects is descriptively not significant.

2. Needs vs Talents and Interests

The average of needs and talents \& interests aspects is different, and the average difference of motivation between these two aspects is descriptively significant.

3. Needs vs Psychology

The average of needs and psychology aspects is different, and the average difference of motivation between these two aspects is descriptively significant.

4. Needs vs Friends

The average of aspects of needs and friends is the same, and the average difference between these two aspects is descriptively not significant.

5. Needs vs Facilities and Infrastructure

The average of needs and facilities and infrastructure aspects is different, and the average difference of motivation between these two aspects is descriptively significant.

6. Needs vs Teacher

The average of needs and teacher aspects is different, and the average difference of motivation between these two aspects is descriptively significant.

7. Hope vs Talents and Interests

The average of hope and talents $\&$ interest aspects is different, and the average difference of motivation between these two aspects is descriptively significant.

8. Hope vs Psychology

The average of hope and psychology aspects is different, and the average difference of motivation between these two aspects is descriptively significant.

9. Hope vs Friends

The average of hope and friends aspects is the same, and the average difference between these two aspects is descriptively not significant. 
10. Hope vs Facilities and Infrastructure

The average of hope and facilities \& infrastructure aspects is different, and the average difference of motivation between these two aspects is descriptively significant.

11. Hope vs Teacher

The average of hope and teacher aspects is different, and the average difference of motivation between these two aspects is descriptively significant.

12. Talents and Interests vs Psychology

The average of talents \& interests and psychology aspects is the same, and the average difference between these two aspects is descriptively not significant.

13. Talents and Interest vs Friends

The average of talents \& interests and friends aspects is different, and the average difference of motivation between these two aspects is descriptively significant.

14. Talents and Interest vs Facilities and Infrastructure

The average of talents $\&$ interests and facilities $\&$ infrastructure aspects is the same, and the average difference between these two aspects is descriptively not significant.

15. Talents and Interest vs Teacher

The average of talents \& interests and teacher aspects is the same, and the average difference between these two aspects is descriptively not significant.

16. Psychology vs Friends

The average of psychology and friends aspects is different, and the average difference of motivation between these two aspects is descriptively significant.

17. Psychology vs Facilities and Infrastructure

The average of psychology and facilities \& infrastructure aspects is the same, and the average difference between these two aspects is descriptively not significant.

18. Psychology vs Teacher

The average of psychology and teacher aspects is the same, and the average difference between these two aspects is descriptively not significant.

19. Friends vs Facilities and Infrastructure

The average of friends and facilities \& infrastructure aspects is different, and the average difference of motivation between these two aspects is descriptively significant.

20. Friends vs Teacher

The average of friends and teacher aspects is different, and the average difference of motivation between these two aspects is descriptively significant.

21. Facilities and Infrastructure vs Teacher

The average of facilities \& infrastructure and teacher aspects is the same, and the average difference between these two aspects is descriptively not significant.

Researchers also wanted to see the similarity from the average of all seven aspects of motivation, including: 
Table 3. Similarity of Average Aspects

\begin{tabular}{|c|c|c|c|c|}
\hline \multicolumn{5}{|l|}{ Motivation } \\
\hline & Aspects & $\mathbf{N}$ & 1 & 2 \\
\hline \multirow[t]{8}{*}{ Tukey HSD ${ }^{\mathrm{a}, \mathrm{b}}$} & Psychology & 1025 & 3.20 & \\
\hline & $\begin{array}{l}\text { Talents } \\
\text { Interests }\end{array}$ & 1230 & 3.22 & \\
\hline & $\begin{array}{l}\text { Facilities and } \\
\text { Infrastructure }\end{array}$ & 820 & 3.22 & \\
\hline & Teacher & 615 & 3.24 & \\
\hline & Hope & 2665 & & 3.39 \\
\hline & Needs & 3074 & & 3.40 \\
\hline & Friends & 410 & & 3.42 \\
\hline & Sig. & & .706 & .758 \\
\hline
\end{tabular}

Means for groups in homogeneous subsets are displayed.

a. Uses Harmonic Mean Sample Size $=900.470$.

b. The group sizes are unequal. The harmonic mean of the group sizes is used. Type I error levels are not guaranteed.

To see the average similarity, Tukey HSD is used in this study. The following are interpretation of the table above:

a. In subset 1, there are data of psychology, talent and interests, facilities and infrastructure, and teacher aspects. This means that the average of these aspects do not have a significant difference. In other words, the average of psychology, talent and interests, facilities and infrastructure, and teacher aspects is the same.

b. In subset 1, there are data of hope, needs, and friends aspects. This means that the average of these aspects do not have a significant difference. In other words, the average of hope, needs, and friends aspects is the same.

From the results above, aspects of friends are being parents' main motivation in choosing bilingual schools for their children.

\section{DISCUSSION}

Bilingual languages for children have still become a controversy in society since it draws people's opinions whether they agree or disagree. According to (Bialystok, 2001: 9), learning two languages would help children's cognitive development. Bilingual ability can strengthen children's concept, creativity, visual-social ability, logic considerations, classification ability, and cognitive flexibility. In fact, bilingual children can improve their education through attending language courses after school or on the weekend. According to Bialystok (2018: 675), bilingual education can open up opportunities to work in the global economy, expand social space, get empowered through languages, arts, and cultures, as well as delay the tendency of dementia.

In previous studies, bilingual children seem to have better understanding in recognizing letters rather than single-language children of the same age. According to Cenoz \& Genesee (1998: 24), bilingual children will have a stronger phonological awareness and are accustomed to listen more carefully.

Previous studies found that it does not mean for bilingual children to always learn to read faster than single-language children. According to Segalowitz dan Hebert in Cumming (1994: 35), most bilingual children are not always that smart or fluent in both languages. Usually, children will be more fluent in their mother language. Although 
learning two languages initially slowed down the development of their vocabulary, bilingual children are trying to learn expressing themselves and eventually become fluent in both languages if they use these both languages consistently.

How can children become bilingual? Bialystok (2001: 73-83) found that when babies are born, they can recognize sound differences in speaking from all languages. However, this ability disappears between the ages of 6-12 months, and this happens when babies begin to speak language they hear most often. According to this research, the earlier children are familiar with a language, the smoother the speech is as the native speaker.

Even though there are previous research which contradict regarding the age limit of a child who cannot have the ability to pronounce a second language like native speakers, some studies suggest to limit the age at 5 years old, 8 years old, and in the puberty phase. Researchers agree that the ability to become fluent in a second language will decrease as the children get older.

To review, the most important thing for parents to understand is that a second language becomes so important for their child's best progress and growth. Teaching children a second language is like a gift since not everyone will have access and opportunity to teach their children, but parents should still pay more attention to their children's development, self-identity, self-esteem, school choices, and other social factors.

\section{CONCLUSION AND RECOMMENDATION}

In this study, the average motivation from the aspects of psychology, talents \& interests, facilities \& infrastructure, and teachers with the aspects of hopes, needs, and friends are found to be different, meanwhile the average (Table 3) on number 1 and 2 is not found, meaning there is no similarity. Thus, motivation variable significantly influences the differences in the aspects of psychology, talents \& interests, facilities \& infrastructure, and teachers with the aspects of hopes, needs, and friends.

In conclusion, the background and reasons of why parents are choosing bilingual schools for their children are influenced by the aspect of friends, in which parents prefer bilingual schools because of following their friends. Another indicator is found that parents are choosing bilingual schools because they are suggested by their friends in their circles.

\section{REFERENCES}

Bialystok, E. (2001). Bilingualism in Development: Language, Literacy, and Cognition (2003rd ed.). Cambridge University Press.

Bialystok, E. (2018). Bilingual education for young children: Review of the effects and consequences. International Journal of Bilingual Education and Bilingualism, 21(6), 666-679. https://doi.org/10.1080/13670050.2016.1203859

Cenoz, J., \& Genesee, F. (1998). Beyond bilingualism: Multilingualism and multilingual education. Multilingual Matters Ltd. http://search.ebscohost.com/login.aspx?direct=true \&scope $=$ site $\& \mathrm{db}=$ nlebk $\& \mathrm{db}$ $=$ nlabk\& $\mathrm{AN}=16680$ 
Cumming, A. H. (Ed.). (1994). Bilingual performance in reading and writing. Language Learning; Distributed by J. Benjamins Pub.

Jambunathan, S. (2005). Beliefs about the Importance of Use of Developmentally Appropriate Practices Among Early Childhood Teachers in India. 275Journal of Early Childhood Teacher Education, Routledge, 26(3), 275-281. https://doi.org/10.1080/10901020500369878

Kementerian Pendidikan dan Kebudayaan RI. (2003). Undang-Undang Republik Indonesia Nomor 20 Tahun 2003 tentang Sistem Pendidikan Nasional. Kementerian Pendidikan dan Kebudayaan RI.

Nasser, I. (2011). Perspectives of Palestinian and Jewish parents in Israel on bilingual education. International Journal of Bilingual Education and Bilingualism, 14(3), 301-318. https://doi.org/10.1080/13670050.2010.497203

Prošić-Santovac, D., \& Radović, D. (2018). Children's vs. teachers' and parents' agency: A case of a Serbian-English bilingual preschool model. Language, Culture and Curriculum, 31(3), 289-302. https://doi.org/10.1080/07908318.2018.1504401

Schinke, L., \& Liano. (1989). Early Childhood Bilingualism (SSLA, Vol. 11). Cambridge University Press. 